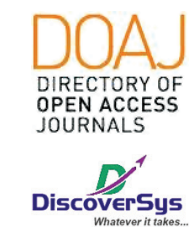

Published by DiscoverSys

\section{Prevalence and clinical manifestations of patients with psoriasis in RSUP Sanglah from 2017 to 2018}

\author{
Daarshawnee Segar, ${ }^{*}{ }^{*}$ IGAA. Dwi Karmila, ${ }^{2}$ IGAA Praharsini, ${ }^{2}$ IGAA. Elis Indira ${ }^{2}$
}

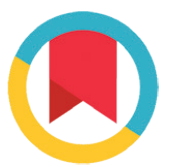

CrossMark

\title{
ABSTRACT
}

Background: Psoriasis is a complex, multifactorial, inflammatory, chronic autoimmune disorder that changes the life cycle of skin cells. In countries around the world, the prevalence of psoriasis ranges from $0.09 \%$ to $11.43 \%$.

Objective: This study aims to determine the prevalence and clinical manifestations of patients with psoriasis in RSUP Sanglah Denpasar from the year 2017 to 2018.

Method: The study used is a descriptive retrospective study design using total sampling with142 samples recorded.

Results: The prevalence of psoriasis was $0.603 \%$ in 2017 and $0.708 \%$ in 2018. Between 2017 till 2018, a total of 142 patients reported having psoriasis with 73 patients (51.4\%) in 2017 and 69 patients
(48.6\%) in 2018. The cases were dominated by males with 90 patients (63.4\%) and females with 52 (36.6\%) for both the years. Psoriasis patients between the ages of $36-45$ years were reported the most with a proportion of $23.2 \%$. The least number of patients were reported below the age of 5 years. There was a total of 63(44.4\%) patients diagnosed with psoriasis vulgaris which is also the most common type of psoriasis case found in Sanglah. The least number of patients were psoriasis inverse and erythrodermic with 4(2.8\%) patients each.

Conclusion: The clinical manifestations used to diagnose psoriasis were red sharp boundaries erythematous plaque, covered with silver or scaly white squamae and geographic skin lesion. This clinical finding was used for almost all psoriasis diagnosis.
'Program Studi Pendidikan Dokter, Fakultas Kedokteran Universitas Udayana

${ }^{2}$ Departemen/SMF IImu Kesehatan Kulit dan Kelamin, Fakultas Kedokteran Universitas Udayana

*Correspondence to: Daarshawnee Segar, Program Studi Pendidikan Dokter, Fakultas Kedokteran Universitas Udayana daarsh17@gmail.com

Received: 2019-04-08 Accepted: 2019-11-24 Published: 2019-12-01

Keywords: prevalence, clinical manifestations, and psoriasis.

Cite This Article: Segar, D., Karmila, I.G.A.A.D., Praharsini, I.G.A.A., Indira, I.G.A.A.E. 2019. Prevalence and clinical manifestations of patients with psoriasis in RSUP Sanglah from 2017 to 2018. Intisari Sains Medis 10(3): 839-844. D0I: 10.15562/ism.v10i3.497

\section{ABSTRAK}

Latar Belakang: Psoriasis adalah kelainan autoimun kronis, multifaktorial, inflamasi, kronis yang mengubah siklus hidup sel kulit. Di negara-negara di seluruh dunia, prevalensi psoriasis berkisar dari 0,09\% hingga $11,43 \%$.

Tujuan: Penelitian ini bertujuan untuk menentukan prevalensi dan manifestasi klinis pasien dengan psoriasis di RSUP Sanglah Denpasar dari tahun 2017 hingga 2018.

Metode: Penelitian yang digunakan adalah desain penelitian retrospektif deskriptif dengan menggunakan total sampling dengan tercatat 142 sampel.

Hasil: Prevalensi psoriasis adalah 0,603\% pada 2017 dan 0,708\% pada 2018. Antara 2017 hingga 2018, total 142 pasien melaporkan memiliki psoriasis dengan 73 pasien $(51,4 \%$ ) pada 2017 dan 69 pasien $(48,6 \%)$ pada 2018. The kasus didominasi oleh laki-laki dengan 90 pasien $(63,4 \%)$ dan perempuan dengan $52(36,6 \%)$ untuk kedua tahun. Pasien psoriasis antara usia 36-45 tahun dilaporkan paling banyak dengan proporsi $23,2 \%$. Jumlah pasien paling sedikit dilaporkan di bawah usia 5 tahun. Ada total $63(44,4 \%)$ pasien yang didiagnosis dengan psoriasis vulgaris yang juga merupakan jenis kasus psoriasis yang paling umum ditemukan di Sanglah. Jumlah pasien yang paling sedikit adalah psoriasis invers dan erythrodermic dengan masingmasing 4 (2,8\%) pasien.

Simpulan: Manifestasi klinis yang digunakan untuk mendiagnosis psoriasis adalah plak eritematosa batas tajam merah, ditutupi dengan skuama putih bersisik dan perak dan lesi kulit geografis. Temuan klinis ini digunakan untuk hampir semua diagnosis psoriasis.

Kata kunci: prevalensi, manifestasi klinis, psoriasis

Cite Pasal Ini: Segar, D., Karmila, I.G.A.A.D., Praharsini, I.G.A.A., Indira, I.G.A.A.E. 2019. Prevalence and clinical manifestations of patients with psoriasis in RSUP Sanglah from 2017 to 2018. Intisari Sains Medis 10(3): 840-844. D0I: 10.15562/ism.v10i3.497

\section{INTRODUCTION}

Psoriasis is a complex, chronic, multifactorial, inflammatory, autoimmune disease that changes the life cycle of skin cells. It occurs in the epidermis, the top five layers of the skin. The process starts in the basal layer of the epidermis, where keratinocytes are produced. In normal cell growth, keratinocytes grow and move from the bottom layer to the skin's surface and shed unnoticed usually within a month. In people with psoriasis, the keratinocytes multiply in about 4 days. The skin cannot shed these cells fast enough, so they build up, leading to thick, dry patches, or plaques. The dermis, 
which contains the nerves and blood and lymphatic vessels, becomes red and swollen. ${ }^{4}$ Environmental, genetic, and immunologic factors appear to play a role. The disease most commonly manifests on the skin of the elbows, knees, scalp, lumbosacral areas, inter-gluteal clefts, and glans penis.

The reported prevalence of psoriasis around the world ranges between $0.09 \%$ and $11.43 \%$, making this disease a serious global problem with at least 100 million individuals affected worldwide. ${ }^{5}$ Psoriasis affects people of all ages, but there is a strong tendency for disease onset in early adulthood in people who develop psoriasis due to genetic factors. According to the American Academy of Dermatology, about 7.5 million people in the United States have psoriasis, with the disease affecting Caucasians more than any other race. ${ }^{4}$

Tracking ways in the incidence and prevalence of psoriasis are difficult, due to the different methodologies of research on this topic. However, an apparent ascending trend is observed in several countries. For example, in 1984, China, the regularity of psoriasis was $0.17 \%$, while 25 years later, another study found it to be $0.59 \%$. The prevalence in Spain in 1998 was $1.43 \%$, while 15 years later it was reported as $2.31 \%$. Data on the prevalence in the United States from the National Health and Nutrition Examination Survey indicated an increase from $1.62 \%$ to $3.10 \%$ from 2004 to 2010 . On 24 May 2014, the Sixty-Seventh World Health Assembly of the World Health Organization (WHO) passed a resolution on psoriasis. ${ }^{5}$ They recognized as well that too many people in the world suffer needlessly from psoriasis due to wrong or delayed diagnosis, inadequate treatment options and insufficient access to care.

The severity of psoriasis varies greatly among different people. Psoriasis patches can range from a few spots of dandruff-like scaling and minor irritation to major eruptions that can cause a great impact on one's life. Psoriasis is a long-lasting disease that usually involves periods when you have no symptoms or mild symptoms, followed by periods when symptoms are more severe and cover large areas of the body. Some psoriasis can clear up within months or sometimes even years. It is known as remission. Other patients experience psoriasis flares in cyclical patterns; for example, the disease will improve in the summer and worsen during winter.

The exact cause of psoriasis is unknown, but it can be triggered by a few factors. The factors that cause psoriasis flares are stress, cold weather, dry skin, vaccinations such as BCG and influenza vaccinations, beta blockers and lithium, upper-respiratory infections, smoking, diet, and alcohol. Patients with psoriasis have a genetic predisposition for the illness. It also tends to cause flares related to systemic or environmental factors to become stronger and weaker. This includes life straining events and infection. It impacts the quality of life and the chances of long-term survival. There should be a high clinical trace of depression in patients with psoriasis

The frequent types of psoriasis are psoriasis vulgaris, guttate psoriasis, inverse psoriasis, pustular psoriasis, and erythrodermic psoriasis. Each type has its own set of symptoms. Most types of psoriasis go through cycles, having flares for a few weeks or months, then settling for a time or even going into complete remission. Although many people have only one form of psoriasis at a time, two different types can simultaneously occur together. One type may change into another type, or become more severe. Common symptoms of psoriasis include; red patches of skin covered with plaques, dry and cracked skin that may bleed, itching, burning, or soreness, thickened, pitted, or ridged nails, swollen and stiff joints.

\section{METHOD}

The type of research method used is a descriptive retrospective study. It is a study in which the disease or condition and potentially related factors are measured at a specific point in time for a defined population. The population that will be used in this research is the number of people that visit RSUP Sanglah each year. The sample is taken from RSUP Sanglah from 2017 to 2018. The study aims to find out the prevalence of psoriasis based on the variables such as age, gender, clinical manifestations that will finally determine the most common psoriasis case in RSUP Sanglah. The technique used for this research is total sampling. Total population sampling is a type of purposive sampling technique that involves examining the entire population (i.e., the total population) that have a particular set of characteristics. The data was analyzed and recorded using Microsoft Excel.

\section{RESULT}

Data collection was carried out at the Rumah Sakit Umum Sanglah from December to February 2018. The data obtained for the research was collected from a total of 142 patients in 2017 and 2018. Based on the records, 73 patients were diagnosed in 2017 and 69 in 2018 as seen in table 2. In 2017, 400 psoriasis cases were recorded. The number increased to 458 visits in 2018. The total number of cases recorded in RSUP Sanglah in 2017 and 2018 are 858 cases. As seen in table 1, the population size used for this research was based on the Yearly Report 2018 of 
Table 1 Prevalence of psoriasis cases in 2017 and 2018 in RSUP Sanglah

\begin{tabular}{cccc}
\hline Year & $\begin{array}{c}\text { Number of old and } \\
\text { new psoriasis cases }\end{array}$ & $\begin{array}{c}\text { Number of patient visits } \\
\text { in RSUP Sanglah }\end{array}$ & Prevalence (\%) \\
\hline 2017 & 400 & 66,282 & 0.603 \\
2018 & 458 & 64,699 & 0.708 \\
\hline
\end{tabular}

Table 2 Distribution of psoriasis patients in 2017 and 2018 in RSUP Sanglah

\begin{tabular}{lcc}
\hline Year & Number of Patients & Proportion (\%) \\
\hline 2017 & 73 & 51.4 \\
2018 & 69 & 48.6 \\
Total & 142 & 100 \\
\hline
\end{tabular}

Table 3 Distribution of psoriasis patients based on gender from 2017 to 2018 in RSUP Sanglah

\begin{tabular}{lcccc}
\hline Gender & \multicolumn{2}{c}{ Year } & $\begin{array}{c}\text { Number of } \\
\text { Patients }\end{array}$ & $\begin{array}{c}\text { Proportion } \\
\text { (\%) }\end{array}$ \\
\cline { 2 - 5 } & Jumlah & $\%$ & 90 & 63.4 \\
Male & 46 & 44 & 52 & 36.6 \\
Female & 27 & 25 & 142 & 100 \\
Total & 73 & 69 & & \\
\hline
\end{tabular}

Table 4 Distribution of psoriasis patients based on age from 2017 to 2018 in RSUP Sanglah

\begin{tabular}{|c|c|c|c|c|}
\hline \multirow[b]{2}{*}{ Age } & \multicolumn{2}{|c|}{ Year } & \multirow{2}{*}{$\begin{array}{l}\text { Number of } \\
\text { Patients }\end{array}$} & \multirow{2}{*}{$\begin{array}{c}\text { Proportion } \\
\text { (\%) }\end{array}$} \\
\hline & 2017 & 2018 & & \\
\hline$<5$ & 1 & 1 & 2 & 1.4 \\
\hline 5-11 & 4 & 3 & 7 & 4.9 \\
\hline $12-16$ & 2 & 1 & 3 & 2.1 \\
\hline $17-25$ & 7 & 9 & 16 & 11.3 \\
\hline $26-35$ & 7 & 15 & 22 & 15.5 \\
\hline $36-45$ & 17 & 16 & 33 & 23.2 \\
\hline $46-55$ & 18 & 14 & 32 & 22.5 \\
\hline $56-65$ & 11 & 9 & 20 & 14.1 \\
\hline$>65$ & 6 & 1 & 7 & 4.9 \\
\hline Total & 73 & 69 & 142 & 100 \\
\hline
\end{tabular}

RSUP Sanglah that stated the number of patients that visit RSUP Sanglah in the year 2017 and 2018 which was 66,282 and 64,699 respectively

\section{DISCUSSION}

Based on the reports and data of the Medical Records Department in Sanglah Hospital in Denpasar, there were 400 and 458 new and old cases in the year 2017 and 2018 respectively. The population size used for this research was based on the Yearly Report 2018 of RSUP Sanglah that stated the number of patients that visit RSUP Sanglah in the year 2017 and 2018 which was 66,282 and 64,699 respectively. ${ }^{7}$

The prevalence recorded in the year 2017 was $0.603 \%$ and in 2018 was $0.708 \%$. There was an increase in psoriasis cases between both years. From January to December 2009, there were 156 new cases of psoriasis from $10856(1,4 \%)$ visits that were examined and treated in RSUP Sanglah. ${ }^{7}$ A 6 months study was conducted in the Dermatology Lab in Sanglah Hospital where 58 samples consisting of 32 patients with psoriasis and 26 subjects without psoriasis as a control. A total of 12 out of 32 patients with psoriasis are associated with an increased level of psychological stress. The epidemiology of psoriasis in various countries varies, with a prevalence range of $0.09 \%$ to $11.43 \%$. Globally, the prevalence of psoriasis ranges between $2 \%$ to $3 \%$.

There were more psoriasis patients reported in 2017 than in 2018. However, the difference was not very prominent as the proportion in 2017 was $51.4 \%$ and in 2017 it was $48.6 \%$. The number of patients decreased by 4 . The reduction might have been due to the effective management and treatment of the disease or the increase of awareness of this disease. The prevalence of psoriasis in Indonesia is reported to vary in each hospital or medical centers. In a research done by Dewi dkk, the data was stated that in 2009 there were 156 cases reported in RSUP Sanglah (1.4\%), ${ }^{5}$ while Rumah Sakit dr. Cipto Mangunkusumo in Jakarta reported a total number of 338 (2.39\%) cases of psoriasis from 2000 to 2002. Whereas in another research done by Angelina dkk in Poliklinik Kulit dan Kelamin RSUP Prof. DR. R. D. Kandou in Manado between January to December tahun 2012, 48 (1,21\%) patients were diagnosed with psoriasis. ${ }^{8}$

Psoriasis is fairly common in both females and males. However, from table 3 , it is noted that in RSUP Sanglah, psoriasis is prevalent mostly in males than in females. The number of male patients reported in 2017 and 2018 was 46 and 44 respectively with a proportion of $63.4 \%$. Female patients were lesser with several 27 in 2017 and 25 in 2018. The proportion for females was $36.6 \%$ for both the years. The data collected is supported by the research done by Dewi dkk, which states that in the year 2012 to 2014 the percentage of psoriasis cases in males was $64.29 \%$ and females $35.71 \%$ which was close to the prevalence in 2017 to 2018 with $63.4 \%$ males and $36.6 \%$ females. ${ }^{5}$ In Poliklinik Kulit dan Kelamin RSUP Prof. DR. R. D. Kandou, Manado the percentage of both genders was almost equal with $56.25 \%$ of males and $43.75 \%$ of females. Psoriasis is considered equally prevalent in both sexes. However, out of all studies that reported prevalence by sex, some studies indicated that psoriasis is more common in men. 
Table 5 The proportion of psoriasis patients based on the classification of psoriasis from 2017 to 2018 in RSUP Sanglah

\begin{tabular}{lcccc}
\hline & \multicolumn{2}{c}{ Year } & Number of & $\begin{array}{c}\text { Proportion } \\
\text { Patients }\end{array}$ \\
\cline { 2 - 5 } Types of Psoriasis & $\mathbf{2 0 1 7}$ & $\mathbf{2 0 1 8}$ & 63 & 44.4 \\
\hline Vulgaris & 31 & 32 & 21 & 14.8 \\
Guttate & 12 & 9 & 4 & 2.8 \\
Inverse & 2 & 2 & 3 & 2.1 \\
Erythrodermic & 2 & 1 & 20 & 14.1 \\
Pustular & 9 & 11 & 9 & 6.3 \\
Arthropathic & 5 & 4 & 21 & 14.8 \\
Unspecified & 12 & 10 & 142 & 100 \\
Total & 73 & 69 & &
\end{tabular}

Table 4 shows the number of psoriasis patients in RSUP Sanglah based on age. The age range was referred from Depkes 2009. There was a child below the age of 5 years in 2017 and 2018. The total number of children reported for both years were $2(1.4 \%)$. There were 4 and 3 children between 5-11 years for 2017 and 2018 respectively with the total 7(4.9\%). Teens between 12-16 years with 2 and 1 patient respectively with a total of $3(2.1 \%)$. Several patients between the age 17-25 years are 7 and 9 with a total of $16(11.3 \%)$. Adults between $26-35$ years were 7 and 15 with a total of $22(15.5 \%)$. The most number of patients reported were between 36-45 with 17 and 16 people in the year 2017 and 2018 with a total of 33(23.2\%). Ages between 46-55 years old were the second most with a total of $32(22.5 \%)$. Middle-aged adults with a total of $20(14.1 \%)$ and above the age of 65 with 7(4.9\%) patients in 2017 and 2018. Psoriasis may appear at any age, but it is uncommon under the age of 10 years. The most number of cases in RSUP Sanglah in 2017 and 2018 were seen in patients between ages 15 to 49 years. In Fitzpatrick's Dermatology of General Medicine, it is stated that the onset of psoriasis is usually between the ages of 15 to 30 years. Possession of certain HLA Class I antigens, particularly HLA-Cw6, is associated with an earlier age of onset and with a positive family history. This finding led Henseler and Christophers to propose that two different forms of psoriasis exist: type I psoriasis, with age of onset before 40 years and HLA-associated, and type II, with age of onset after 40 years. ${ }^{9}$

The types of psoriasis were classified into psoriasis vulgaris, guttate, inverse, erythrodermic, pustular, arthropathies or arthritis, and the ones that couldn't be identified due to the lack of information in the medical records were named unspecified psoriasis as seen in table 5. There was a total of 63(44.4\%) patients diagnosed with psoriasis vulgaris which is also the most common type of psoriasis case found in RSUP Sanglah. The second common psoriasis was guttate with several $21(14.8 \%)$ patients diagnosed for both the years. The least number of patients were psoriasis inverse and erythrodermic with $4(2.8 \%)$ patients each. The next one is generalized pustular psoriasis with a total of 20(14.1\%) patients in 2017 and 2018. Arthropathic psoriasis or psoriasis arthritis has several 9(6.3\%) patients. The number of unspecified psoriases was $21(14.8 \%)$ due to the lack of information in the medical records, and this will be under the exclusive criteria for psoriasis. The data collected from RSUP Sanglah for the types of psoriasis in 2017 and 2018 varies with psoriasis vulgaris being the highest recorded psoriasis. In research done by Dewi dkk in RSUP Sanglah, in the period between 2012 to 2014, psoriasis vulgaris had a prevalence of $77.14 \%$. Besides that, in Poliklinik Ilmu Kesehatan Kulit dan Kelamin RSUP dr. Mohammad Hoesin Palembang from August 2008 to June 2012, the number of psoriasis vulgaris cases alone were 491 cases. $^{10}$

The types of psoriasis cases recorded in RSUP Sanglah were psoriasis vulgaris, psoriasis guttate, inverse psoriasis, erythrodermic psoriasis pustular psoriasis arthropathic and unspecified psoriasis. These cases were then studied to find the clinical manifestations that were used to diagnose the patients. Some of the cases were found to have more than one diagnosis due to the manifestations seen. About $44.4 \%$ of the cases in RSUP Sanglah in the period between 2017 and 2018 were psoriasis vulgaris. Most of the skin efflorescence of psoriasis vulgaris were sharp red boundaries erythematous plaques, covered with pearlescent or scaly white squamae. Geographic plaque skin lesions were found with positive Auzpitz sign and Koebner phenomenon for most cases. Other findings such as pitting nails were seen but very rare. These manifestations were found mostly in areas such as the scalp, elbows, knees, chest, legs, hands and lower back. ${ }^{9}$ The second most common psoriasis cases found were psoriasis guttate with 14.8\% in 2017 and 2018. Clinical findings such as hyperpigmented macules, salmon patch, teardrop lesions, and geographic erythematous plaques with diameter 0.5 to $2 \mathrm{~cm}$ wide were found. Guttate psoriasis can occur as an initial diagnosis for psoriasis vulgaris. Sometimes, patients are diagnosed with both types due to clinical manifestations. The patches usually appear on the upper and lower extremities and the scalp. The least number of cases was reported for inverse psoriasis with $2.8 \%$. Inverse psoriasis patients are seen with smooth inflamed patches in areas such as the arm folds, groin and between the buttocks. Erythrodermic psoriasis also has the least amount of cases with the same prevalence as inverse psoriasis. The cases were very similar to psoriasis vulgaris, and it covers almost the whole body. Generalized pustular psoriasis is one of the 
common cases in Sanglah. Patients with this type of psoriasis are seen with red patches and pustules which are usually due to complications of psoriasis vulgaris. The multiple erythematous macules are found with a lake of pus and can spread to various parts of the body such as the upper and lower extremities and lower back. A few arthropathic psoriasis cases were found. Skin lesions appear before the onset of arthritis, and this affects mostly in the distal interphalangeal joints of the hands and feet. About $14.8 \%$ of cases were unspecified psoriasis that might have occurred due to other various underlying complications. ${ }^{6}$

\section{CONCLUSION}

It is a suggestion that health care institutions can provide more information or counseling to the public regarding the clinical manifestation of psoriasis, management, and treatment of psoriasis and the disease itself. This study is expected to be a motivation for further research in more samples, especially the researches done in the province of Bali by looking for the clinical manifestations of psoriasis.

\section{CONFLICT OF INTEREST}

The author states that there is no conflict of interest regarding the publication of this article.

\section{FUNDING}

This research does not get funding provided by the government or other private institutions.

\section{AUTHOR CONTRIBUTION}

Research concept: Daarshawnee Segar, IGAA. Dwi Karmila, IGAA Praharsini, IGAA. Elis Indira. Data collection, data input and data processing: Daarshawnee Segar. Preparation of Research manuscript: Daarshawnee Segar.

\section{ETHICAL CLEARANCE NUMBER}

\author{
1599/UN.14.2.2/KEP/2018.
}

\section{REFERENCES}

1. Cholis A, Prevalensi psoriasis di sepuluh rumah sakit besar di Indonesia. KONAS Perdoski Surabaya. 1999.

2. Kristin Altman. Guttate Psoriasis. Psoriasis. 2016.

3. Athieqah AD. Psoriasis. Epidemiologi Psoriasis. 2011.

4. Simon H. Psoriasis. University of Maryland Medical Centre. 2012.

5. WHO. Global Report on Psoriasis. World Health Organization. 2016.

6. Jeffrey MM. Psoriasis. MedScape. 2016.

7. Sudana IW. Laporan Tahunan 2018. Denpasar: RSUP Sanglah. 2018.

8. Angellina M. Profil psoriasis di poliklnik kulit dan kelamin. Profil psoriasis di poliklnik kulit dan kelamin. 2015

9. Johann GJE. Psoriasis. In L. A. Goldsmith, Fitzpatrick Dermatology in General Medicine New York: McGraw Hill. 2012. pp. 197-231.

10. Alyssa A. Angka Kejadian Psoriasis Vulgaris di Poliklinik Ilmu Kesehatan Kulit dan. MKS. 2014.

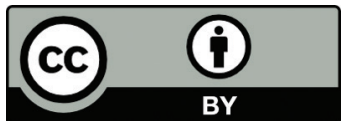

This work is licensed under a Creative Commons Attribution 